\title{
On four sibling Erigone species occurring in the Arctic (Aranei: Linyphiidae)
}

\section{О четырех бцизких видах Erigone, распространенных в Арктике (Aranei: Linyphiidae)}

\author{
Yuri M. Marusik ${ }^{1-2}$, Anna A. Nekhaeva ${ }^{3}$, Seppo Koponen ${ }^{4}$ \\ Ю.М. Марусик ${ }^{1-2}$, А.А. Нехаева ${ }^{3}$, С. Копонен ${ }^{4}$
}

\footnotetext{
${ }^{1}$ Institute for Biological Problems of the North RAS, Portovaya Str. 18, Magadan 685000, Russia. E-mail: yurmar@mail.ru

${ }^{2}$ Department of Zoology \& Entomology, University of the Free State, Bloemfontein 9300, South Africa.

${ }^{3}$ A.N. Severtsov Institute of Ecology and Evolution, Russian Academy of Sciences, Leninsky prospekt 33, Moscow 119071, Russia.

${ }^{4}$ Zoological Museum, Biodiversity Unit, FI-20014 University of Turku, Finland.

${ }^{1}$ Институт биологических проблем Севера, ДВО РАН, ул. Портовая, 18, 685000 Магадан, Россия.

${ }^{3}$ Институт проблем экологии и эволюции им. А.Н. Северцова РАН, Ленинский проспект, 33, Москва 119071, Россия.
}

KEY WORDS: Araneae, spider, Erigoninae, tundra, distribution, shore communities, size variation.

КЛЮЧЕВЫЕ СЛОВА: Araneae, пауки, Erigoninae, тундра, распространение, прибрежные сообщества, размерные вариации.

ABSTRACT. Four similar species belonging to the Erigone longipalpis group and cooccurring in the tundra zone are illustrated and diagnosed: E. arcticola Chamberlin et Ivie, 1947, E. hypoarctica Eskov, 1989, E. longipalpis (Sundevall, 1830) and E. remota L. Koch, 1869. Their distribution is commented on, all of the species have disjunctive ranges, either west-east, or north-south. Study of size variations of all four species, each taken from a single population, revealed that $E$. arcticola, E. hypoarctica and E. longipalpis can be differentiated by carapace length / femur I length ratios. Erigone remota displays a high level of size variation, overlapping with all three other species.

How to cite this article: Marusik Yu.M., Nekhaeva A.A., Koponen S. 2019. On four sibling Erigone species occurring in the Arctic (Aranei: Linyphiidae) // Arthropoda Selecta. Vol.28. No.1. P.135-146. doi: 10.15298/arthsel. 28.1.12

РЕЗЮМЕ. Проиллюстрированы и диагностированы четыре близких вида группы Erigone longipalpis, совместно встречающиеся в тундровой зоне: E. arcticola Chamberlin et Ivie, 1947, E. hyроarctica Eskov, 1989, E. longipalpis (Sundevall, 1830) и E. remota L. Koch, 1869. Прокомментировано их распространение. Все виды имеют дизъюнкции в apeале. Показано, что представители E. arcticola, E. hypoarctica и E. longipalpis отличаются между собой соотношением длины карапакса к длине бедpa I. Erigone remota демонстрирует высокую вариацию в размерах, перекрывающихся со другими тремя видами.

\section{Introduction}

Erigone Audouin, 1826, with 111 named species, is among the top five largest genera of Linyphiidae. So far, only Agyneta Hull, 1911, Lepthyphantes Menge, 1866, and Walckenaeria Blackwall, 1833 have more species [WSC, 2019: 197, 168 and 198 correspondingly]. Being the type genus for Erigoninae, Erigone was for long time a wastebasket for small linyphiids. Many species of unclear belonging were placed in Erigone. Over 100 species have been transferred to other genera or considered as nomina dubia [WSC, 2019]. The genus has a global distribution, but most of the species (81) occur in the Holarctic [WSC, 2019]. Erigone reaches high densities in Arctic communities, for example, four species of Erigone in Dolgyi Island [Marusik et al., 2016] composed $30 \%$ of all spider specimens collected. Erigone is also an abundant genus in marshes along the sea, at least in the Arctic and Sea of Okhotsk. The value of Erigone in the marshes near Magadan exceeds $88 \%$ (unpublished personal data). Although this genus is very abundant, identification of its species is difficult, due to the similarity of some species and lack of proper figures showing differences. While working in several localities in the tundra zone we faced difficulties in distinguishing females of E. longipalpis (Sundevall, 1830) and E. remota L. Koch, 1869 which have very similar epigynes, and males of E. remota and E. arcticola Chamberlin et Ivie, 1947 which have similar embolic divisions. The male of E. arcticola was illustrated only in one publication and the figures are not comparable with existing figures of similar species. Because of the afore-mentioned reasons we decided to 
provide this study and demonstrate how to distinguish four similar species occurring in the Arctic and shore habitats in Siberia.

\section{Material and methods}

Specimens were photographed at the Zoological Museum (University of Turku, Finland) with a Canon EOS 7D camera attached to an Olympus SZX16 stereomicroscope and a SEM JEOL JSM-5200 scanning microscope. Digital images were montaged using CombineZP and Helicon focus 3.10 image stacking software. Epigynes were cleared in a $\mathrm{KOH} /$ water solution until soft tissues were dissolved. Photographs were taken in dishes with paraffin on the bottom holding the specimens in place.

All measurements are given in millimeters. The map given in this work was made to show the distribution of the four species in the Arctic and Siberia. Besides material studied by us we considered records given by experts in taxonomy of Linyphiidae and skipped few ecological papers.

The material treated here will be deposited in the Zoological Museum of the Moscow State University, Russia (ZMMU), the Zoological Museum of the University of Turku, Finland (ZMUT) and Institute for Biological Problems of the North, Magadan (IBPN).

TERMINOLOGY. There is no fixed terminology concerning male palpal parts and epigyne. Here we are using a few terms for the palpal or epigynal parts that are useful for distinguishing the four similar species.

\section{Taxonomic survey}

\section{Erigone Audouin, 1826}

TYPE SPECIES: Linyphia longipalpis Sundevall, 1830 by ICZN decision [ICZN, 1987].

NOTE. Originally Erigone vagans Audouin, 1826 was considered to be the type of the genus, but Millidge [1984] recognized that it differed from most of the other Erigone species and instead of transferring over a hundred species to a new or another genus, he recommended to the ICZN a change of the type species.

COMMENTS. Although Erigone is a species rich genus there have been no real attempts to combine species into the groups. So far, only one group name was used in the literature, but without specifying what species belonged in to it, the E. psychrophila group [Crosby, Bishop, 1928; Muster, Hänggi, 2009]. The four species considered in this paper are related to each other and therefore can be placed in the $E$. longipalpis group.

DISTINGUISHING SPECIES. Here we list characters that allow separation of the four similar species. All these four species co-occur in northeastern part of Europe, Polar Ural. Males of the four species can be separated by many characters such as spines of the palpal femur, relative length of palpal patella and tibia (equal length in E. longipalpis and E. remota, vs. patella longer than tibia in E. arcticola), relative length of palpal tibia and its terminal width, shape and size of dorsal tibial apophysis and its pit; shape of retrolateral tibial apophysis either with 2 teeth or laminar in ventral view and its terminal width. There are differences in the shape of paracymbium (cf. Fig. 2C and Fig. 2A, B); in the shape of posterior tooth of radix, shape of tegulum (cf. Fig. 5A and D), and several others, but the most easily observed character is the shape of anterior tooth of the radix in retrolateral view.

Females of two species, Erigone hypoarctica and E. arcticola, differ significantly from the other two by the shape of the plate and its outer surface lacking distinct furrows. Erigone longipalpis and E. remota have almost identical epigynes and can be easily confused.

Erigone arcticola Chamberlin et Ivie, 1947 Figs 1D, 2B, 3C, E, 4D, 5A-C, 6A, B, 7C-G, 9, 10.

Erigone arcticola Chamberlin et Ivie, 1947: 37, pl. XI. f. 98 (+); Holm, 1960: 115, Pl. II, f. 12-15 ( $\left.\sigma^{\top}+\right)$; Tanasevitch, 2013: 279 , f. $66(+)$. fied].

Erigone arctophylacis: Holm, 1973: 82, f. 35 () [misidenti-

MATERIAL EXAMINED: RUSSIA, NE Siberia: Magadan Area: $3 \sigma^{7} \sigma^{\top} 2$ 우 (IBPN), $29 \mathrm{~km}$ N of Magadan, Dukcha River valley, 1.06.1986 (Yu.M. Marusik). Wrangel Isl.: $\sigma^{7} \sigma^{7} \circ{ }^{\prime},(\mathrm{ZMUT})$, SC part, Sominitel'nyye Mts., $70^{\circ} 58.970^{\prime} \mathrm{N} 179^{\circ} 35.200^{\prime} \mathrm{W}$, VIVIII.2006 (O.A. Khrulyova); $1 \sigma^{\top} 5$ क् (ZMMU), same island, SE part, Mamontovaya R., middle flow, $71^{\circ} 09.592^{\prime} \mathrm{N} 179^{\circ} 45.490^{\prime} \mathrm{W}$, 1992-1994, (O.A. Khrulyova); $1 \sigma^{7}$, (ZMUT), same island, upper flow of Neizvestnaya R., VI-VIII.2006 (O.A. Khrulyova).

DIAGNOSIS. Males of E. arcticola are most similar to those of E. remota and differ by the larger size of the palp and relatively larger size of the anterior tooth of the radix (At) (cf. Fig. 1D \& E, Fig. 2B \& C). Palps of the two species also differ in the shape of the dorsal tibial apophysis (Figs 1 and 5, differences arrowed). Females of E. arcticola differ significantly from $E$. longipalpis and E. remota in the smooth surface of the epigynal plate and in the median plate $(\mathrm{Mp})$ being as wide as long (vs. wider than long in all other species).

Both sexes of E.arcticola have longer carapaces than the other species (see Fig. 9) at least among populations that we compared.

COMMENTS. This species is similar to the poorly known E. arctophylacis Crosby et Bishop, 1928, a species known from the Nearctic. Erigone arctophylacis was never properly illustrated. Judging from the figures sent to us by $\mathrm{G}$. Blagoev, it has small teeth on ventral tibial apophysis lacking in E. arcticola, and epigyne has a semiround median plate, wider than long (vs. a tapering subtriangular median plate as wide as long in E. arcticola).

HABITATS. In the Upper Kolyma this species inhabits mountain tundra and can be found there along creeks under pebbles. It is much more common on pebbly river banks within Chosenia riverside forests in northern Cisokhotia (personal data).

DISTRIBUTION. This species has a Siberian-Alaskan range and properly documented from Novaya Zemlya to Seward Peninsula, and south to Altai (ca. $50^{\circ} \mathrm{N}$ ) and northern Cisokhotia (ca. $\left.60^{\circ} \mathrm{N}\right)$ (Fig. 10). It is the northernmost of the species treated here. Erigone arcticola was found north to $73^{\circ} \mathrm{N}$ in Novaya Zemlya and ca. $71^{\circ} \mathrm{N}$ on Wrangel Island. Records of this species from British Columbia [Bennet et al., 2017] may refer to similar E. arctophylacis. In western Siberia there is a disjunction between the tundra zone and the mountains of South Siberia. It is worth noting that a single female was found in Altai, and the figure of its epigy- 


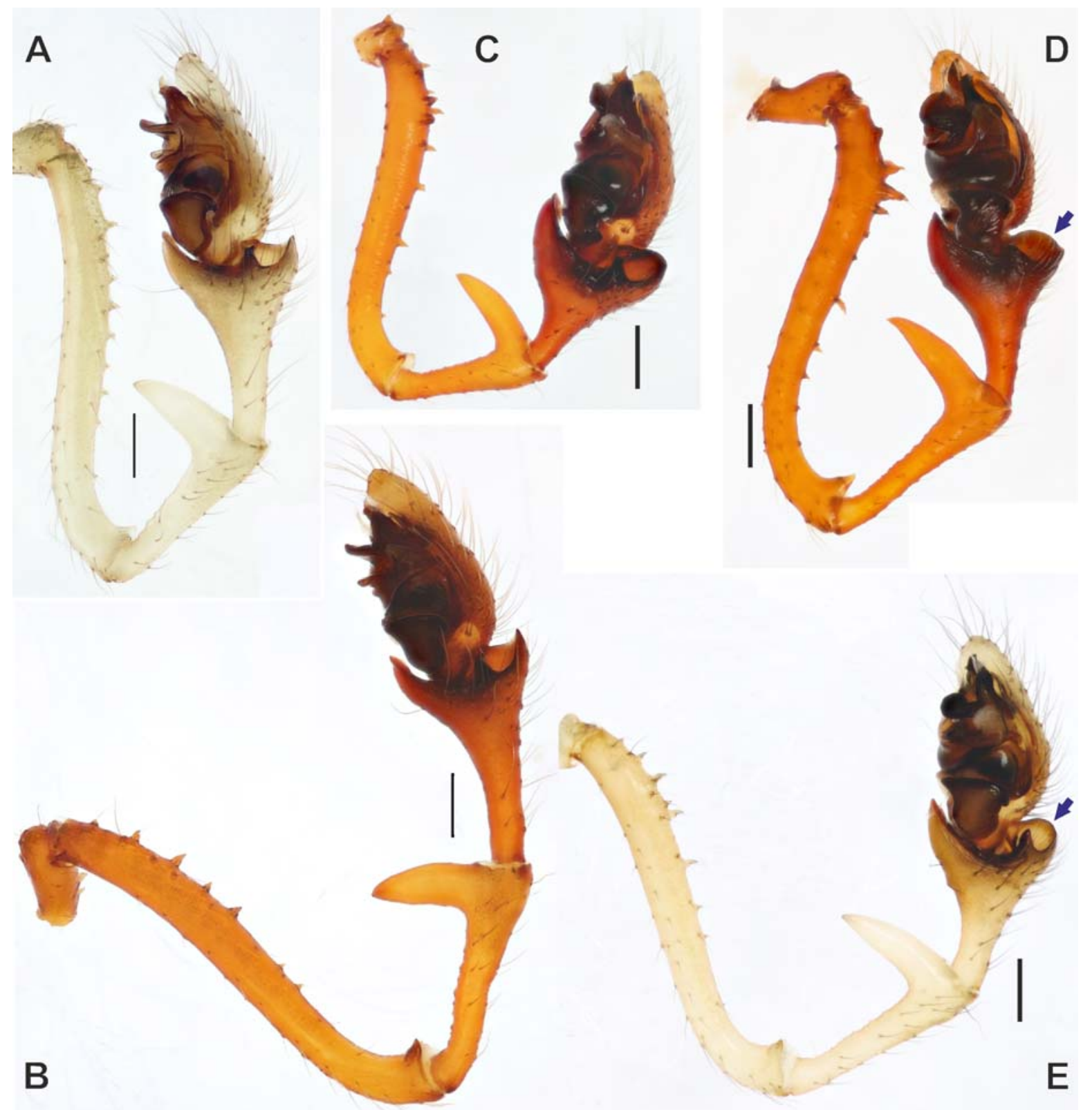

Fig. 1. Retrolateral view the male palp of Erigone longipalpis (A, B), E. hypoarctica (C), E. arcticola (D) and E. remota (E). C from Tauysk; B, E - from Apapelgino; D - from Wrangel Isl. Scale $=0.2 \mathrm{~mm}$.

Рис. 1. Пальпа самца, ретролатерально: Erigone longipalpis (A, B), E. hypoarctica (C), E. arcticola (D) и E. remota (E). C экземпляр из Тауйска; В, Е - из Апапельгино; D - c о. Врангеля. Масштаб = 0,2 мм.

ne [Tanasevitch, 2013: f. 66] corresponds well to our specimens. Tanasevitch [2013] reported this species from Kazakhstan, although his record refers to the Russian Altai.

\section{Erigone hypoarctica Eskov, 1989}

Figs $1 \mathrm{C}, 2 \mathrm{~A}, 3 \mathrm{~B}, \mathrm{~F}, 5 \mathrm{D}-\mathrm{F}, 6 \mathrm{C}-\mathrm{D}, 7 \mathrm{M}-\mathrm{P}, 8 \mathrm{~A}-\mathrm{B}, 9,10$.

Erigone hypoarctica Eskov, 1989: 103, f. 34-37 ( (07)

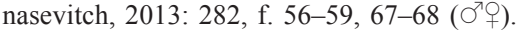

MATERIAL EXAMINED: RUSSIA: Yamalo-Nenents AO: 9 $\sigma^{7} \sigma^{7} 1$ (ZMMU), $73 \mathrm{~km} \mathrm{NE}$ of Labytnangi, foothills of Kharcheruz' Mt. Range, Longotiegan R., $\sim 175 \mathrm{~m}, 67.3^{\circ} \mathrm{N} 66.72^{\circ} \mathrm{E}$, 1-30.07.2015 (V.K. Zinchenko). Magadan Area: $60^{7} 0^{7} 2$ 우
(ZMMU), env. of Tauysk, $59^{\circ} 43^{\prime} 51^{\prime \prime} \mathrm{N} 149^{\circ} 22^{\prime} 47^{\prime \prime} \mathrm{E}$, seashore, pitfall traps, 15-26.07.2017 (M. Bizin, B. Efeikin); 3 ○ $^{7} \sigma^{7} 4$ 우 (IBPN), $50 \mathrm{~km} \mathrm{~N}$ of Magadan, Splavnaya Vil., Khasyn River valley, 28.05.1986 (Yu.M. Marusik).

COMMENTS. This species is known from only two taxonomic entries [WSC, 2019].

DIAGNOSIS. Male of this species can be easily distinguished from the related species by short (as long as wide) and truncated anterior tooth of the radix $(A t) v s$. rounded in E. arcticola and E. remota or digitiform in E. longipalpis. Unlike in similar species, the posterior tooth of the radix $(P t)$ is larger than anterior one. 

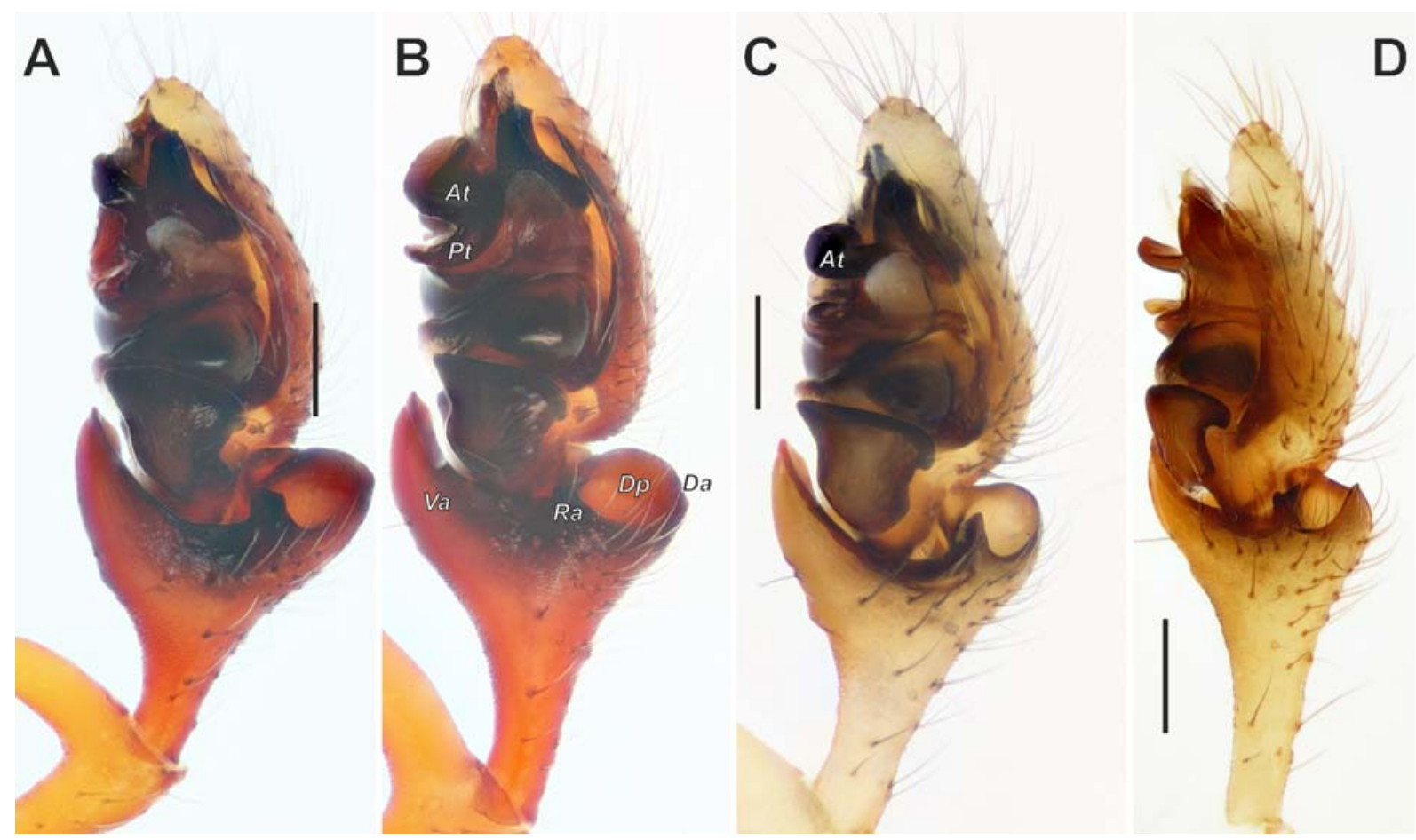

Fig. 2. Retrolateral view of the terminal part of the male palp of Erigone hypoarctica (A), E. arcticola (B), E. remota (C) and E. longipalpis (D). Scale $=0.2 \mathrm{~mm}$.

Рис. 2. Терминальная часть пальпы самца, ретролатерально: Erigone hypoarctica (A), E. arcticola (B), E. remota (C) and E. longipalpis (D). Масштаб = 0,2 мм.

Females of E. hypoarctica differ significantly from those of the three other species considered in this work by the truncate or even concave posterior edge ( $v s$. cambered in other species). In addition, females of this species differ by having no posterior notch $(P n)$ which is present in the three other species.

HABITATS. In Altai this species was found in taiga at the elevations of 500-800 m [Tanasevitch, 2013]. In the Upper Kolyma it inhabits pebbly river and creek banks and vegetation along the pebbly banks on elevations of 300-500 $\mathrm{m}$ (personal data). In the type locality, Ayan Lake it was found along a stream among vegetation [Eskov, 1989].

DISTRIBUTION. Erigone hypoarctica has a Siberian range and occurs from Archangelsk Area to Western Chukotka, and south to Altai and Amur River (Fig. 10). In Western Siberia it has a disjunction between the tundra zone and the mountains of South Siberia. In Central and Eastern Siberia, it is known both in tundra and taiga zones.

Erigone longipalpis (Sundevall, 1830)

Figs 1A, B, 2D, 3D, 4C, E, G, 5G-I, 6E, F, 7H-L, $8 \mathrm{C}-\mathrm{E}, 9,10$

Erigone longipalpis: Wiehle, 1960: 576, f. 1071-1077 (O'+); Palmgren, 1976: 66, f. 11.1, 6, 12.7 (О'o); Roberts, 1987: 95, f 43e, 47a $\left(0^{7}+\right)$

For a complete list of taxonomic references see WSC [2019].

MATERIAL EXAMINED: FINLAND: $\sigma^{\top} \sigma^{7}$ (ZMUT), $\boldsymbol{S} \boldsymbol{W} \boldsymbol{A} \boldsymbol{r}$ chipelago, Korppoo Jurmo, seashore, 17.08.-12.10.1968 (P.T. Lehtinen); 1 ㅇ (ZMUT), same locality, 16.05.-17.07.1968 (P.T. Lehtinen); 오 (ZMUT), Naantali, Luonnonmaa, Käkölä, seashore meadow, 9.09.-3.11.1970 (R. Mannila); 우 (ZMUT), same locali-

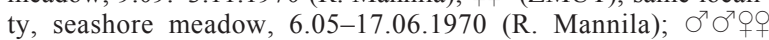

(ZMUT) Houtskari, Jungfruskär, seashore meadow, $60^{\circ} 08^{\prime} \mathrm{N} 21^{\circ}$ 13'E, 22.05.-11.09.2007 (S. Koponen); $3 \sigma^{7} \sigma^{7} 8$ 우, (ZMUT), Aland Islands, Lumparland, Krokstadt, shore, 14.06 .1972 (P.T. Lehtinen); 2 우 (ZMUT), Brändö, Fiskö, shore, 1959 (P.T. Lehtinen). RUSSIA: ca. 770 o' + (ZMMU), Murmansk Area, Kola Peninsula, sea meadow on the left bank of the Kola Gulf, $68^{\circ} 54.36^{\prime} \mathrm{N}$ $33^{\circ} 01.54^{\prime} \mathrm{E}, 28.06-15.09 .2010$ (A. Nekhaeva); 35 O $^{\top} \mathrm{O}^{\top}++$ (ZMMU), same locality, 14.05-9.10.2011 (A. Nekhaeva); ca. 460 ơ (ZMMU), same locality, 1.05-17.10.2012 (A. Nekhaeva); ca. 50 $\sigma^{\top} \uparrow$ (ZMMU), Arkhangelsk Area, Barents Sea, Dolgiy Isl., $69^{\circ} 12^{\prime} \mathrm{N}$ 59 $13^{\prime} \mathrm{E}$, Nenets Reserve, 6-28.07.2004 (O. Makarova); ca. 570 $\mathrm{O}^{7}+$ (ZMMU), Yugorskiy Peninsula, env. of Amderma, sea marshes, 4-18.07.2018 (M. Bizin, B. Efeikin).

COMMENTS. It is the type species of the genus and it has 36 taxonomic entries [WSC, 2019], but only few of the publications provide essential details of the male palp and epigyne conformation.

DIAGNOSIS. Males of this species can be distinguished from similar species by digitiform anterior and posterior teeth of the radix ( $v s$. rounded or abrupt in other species) and also by the concave margin of the dorsal tibial apophysis with distinct angle ( $v s$. cambered and lacking angles). Females of E. longipalpis are very similar to those of $E$. remota. Two species have almost indistinguishable epigynes with inclined furrows near posterior edge (Fig. 4F, G). Erigone longipalpis has 2 furrows on each side, while E. remota has one pair (cf. Fig. 7H, J and A).

HABITATS. According to Harvey et al. [2002] within the UK, Erigone longipalpis: "usually occurs in wet habitats, often at ground level in coastal estuaries and saltmarsh, sometimes with E. arctica. Inland it is associated with damp grassland within river flood plains... Adults can probably be found all year, but mainly in summer and autumn." 

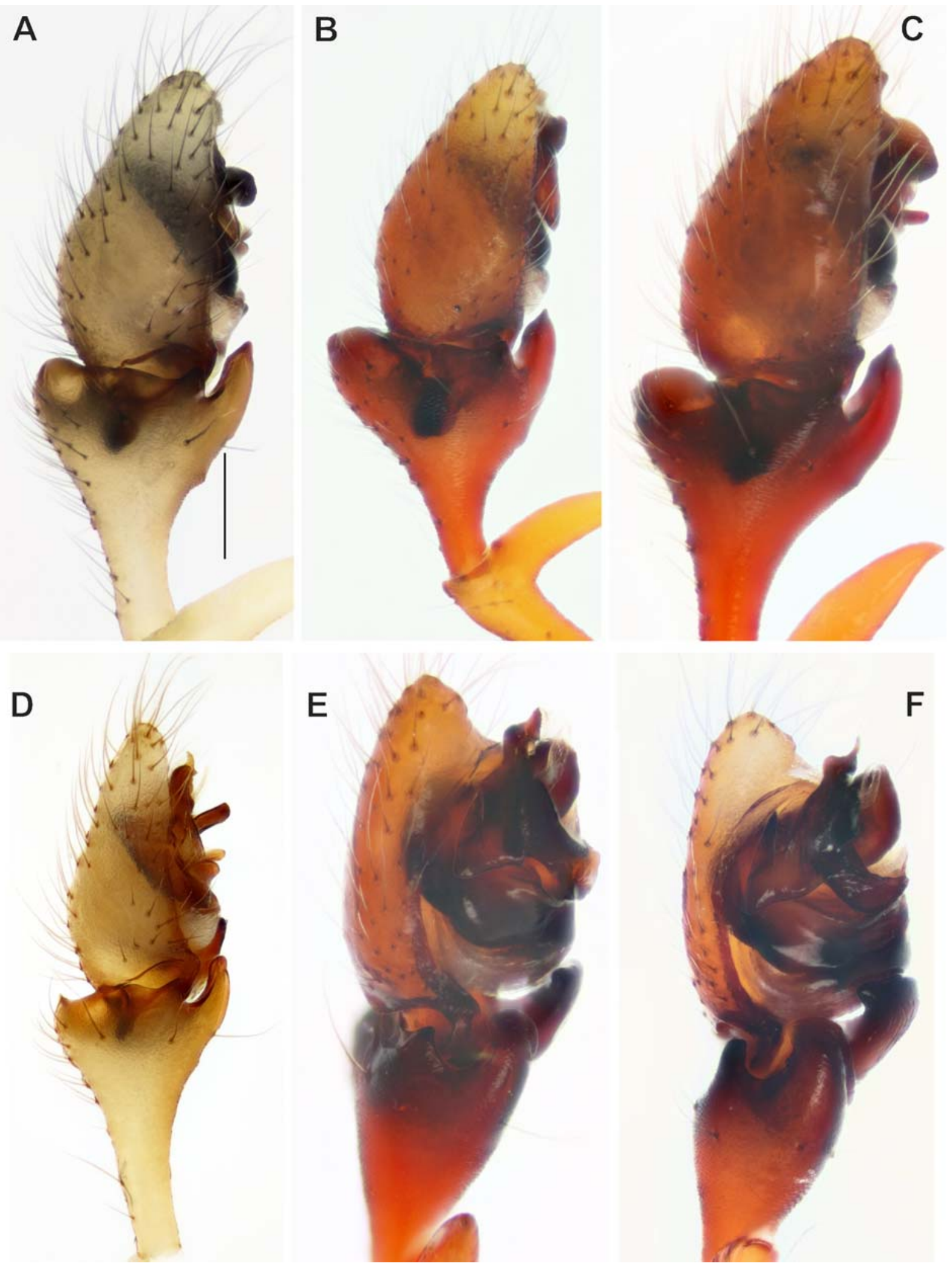

Fig. 3. Male palp of Erigone remota (A), E. hypoarctica (B, F), E. arcticola (C, E), E. longipalpis (D). A-D - dorso-prolateral; E$\mathrm{F}$ - prolateral. Scale $=0.2 \mathrm{~mm}$.

Рис. 3. Пальпа самца Erigone remota (A), E. hypoarctica (B, F), E. arcticola (C, E), E. longipalpis (D). A-D - дорзопролатерально; Е-F — пролатерально. Масштаб = 0,2 мм. 


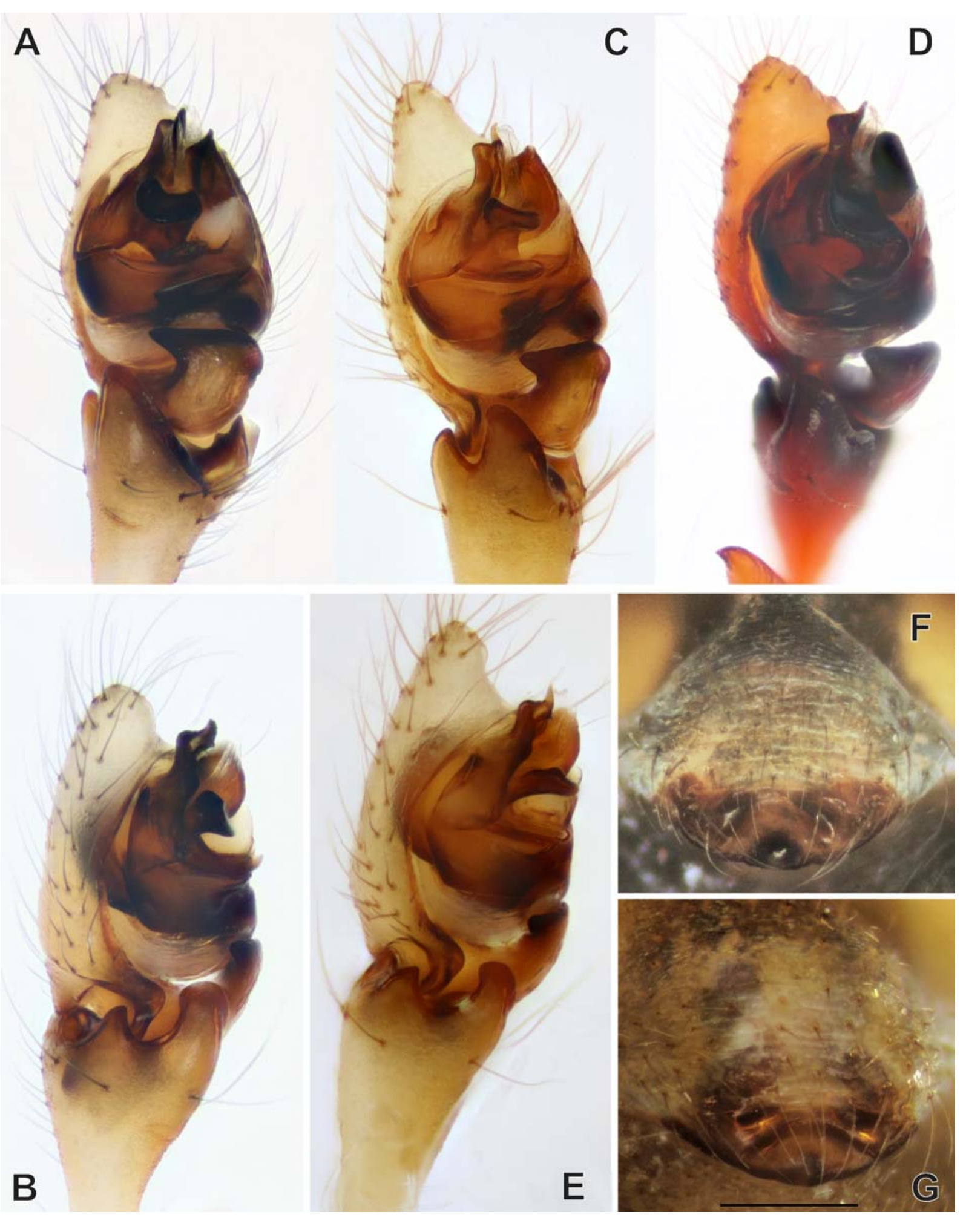

Fig. 4. Copulatory organs of Erigone remota (A, B, F), E. longipalpis (C, E, G), E. arcticola (D). A, C, D - male palp, ventral; B, E male palp, prolateral; F, G - intact epigyne, ventral. Scale $=0.2 \mathrm{~mm}$.

Рис. 4. Копулятивные органы Erigone remota (А, В, F), E. longipalpis (C, E, G), E. arcticola (D). A, C, D — пальпа самца, снизу; $\mathrm{B}, \mathrm{E}$ - пальпа самца, пролатерально; F, G - интактная эпигина, снизу. Масштаб $=0,2$ мм. 

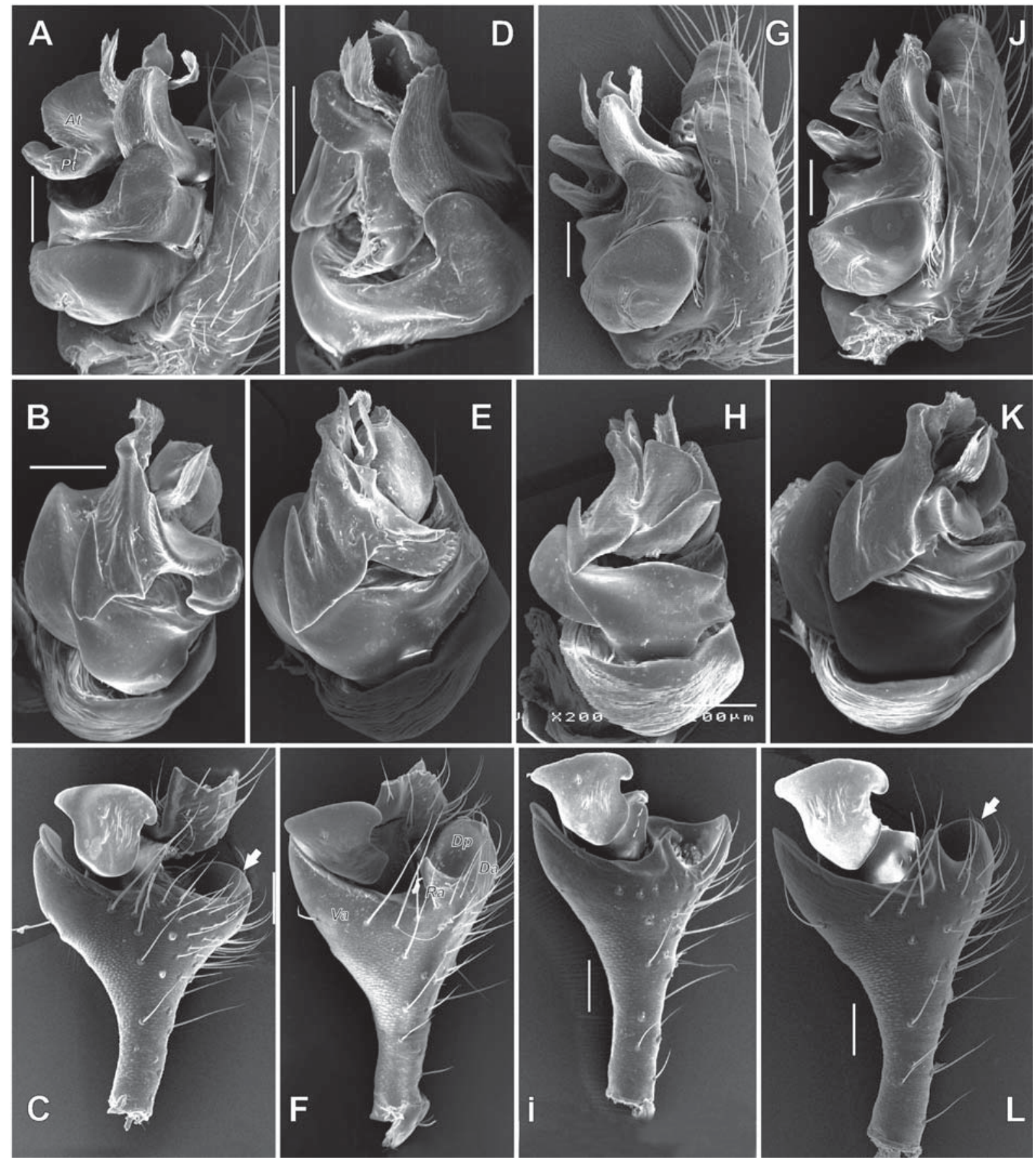

Fig. 5. Male palp of Erigone arcticola (A-C), E. hypoarctica (D-F), E. longipalpis (G-I) and E. remota (J-L). A, D, G, J retrolateral; B, E, H, K - bulb, ventro-prolateral; C, F, I, L - palpal tibia and paracymbium, retrolateral. Scale $=0.1 \mathrm{~mm}$.

Рис. 5. Пальпа самца Erigone arcticola (A-C), E. hypoarctica (D-F), E. longipalpis (G-I) и E. remota (J-L). A, D, G, J ретролатерально; В, Е, Н, К - бульбус, вентро-пролатерально; C, F, I, L - голень пальпы и парацимбиум, ретролатерально, Масштаб $=0,1$ мм.

On the Kola Peninsula and in Finland, this species is found only on sea shores of the Barents Sea and Baltic Sea, respectively (see also Palmgren, 1976). It lives mainly on shore meadows and marshes. In southwestern archipelago of Finland, E. longipalpis has been found also on damp pond sides near the shore [Koponen, 2000], and Lehtinen \& K1eemola [1962] reported it under stones and among wrack on the seashore. It can reach huge numbers, and its greatest activity occurs in the first half of summer [Nekhaeva, 2015, unpublished personal data].

DISTRIBUTION. According to the WSC [2019] Erigone longipalpis is known from Europe, Caucasus, China and Japan. Platnick [2014] indicated distribution of this species as Palaearctic. It appears that this species has a disjunctive 

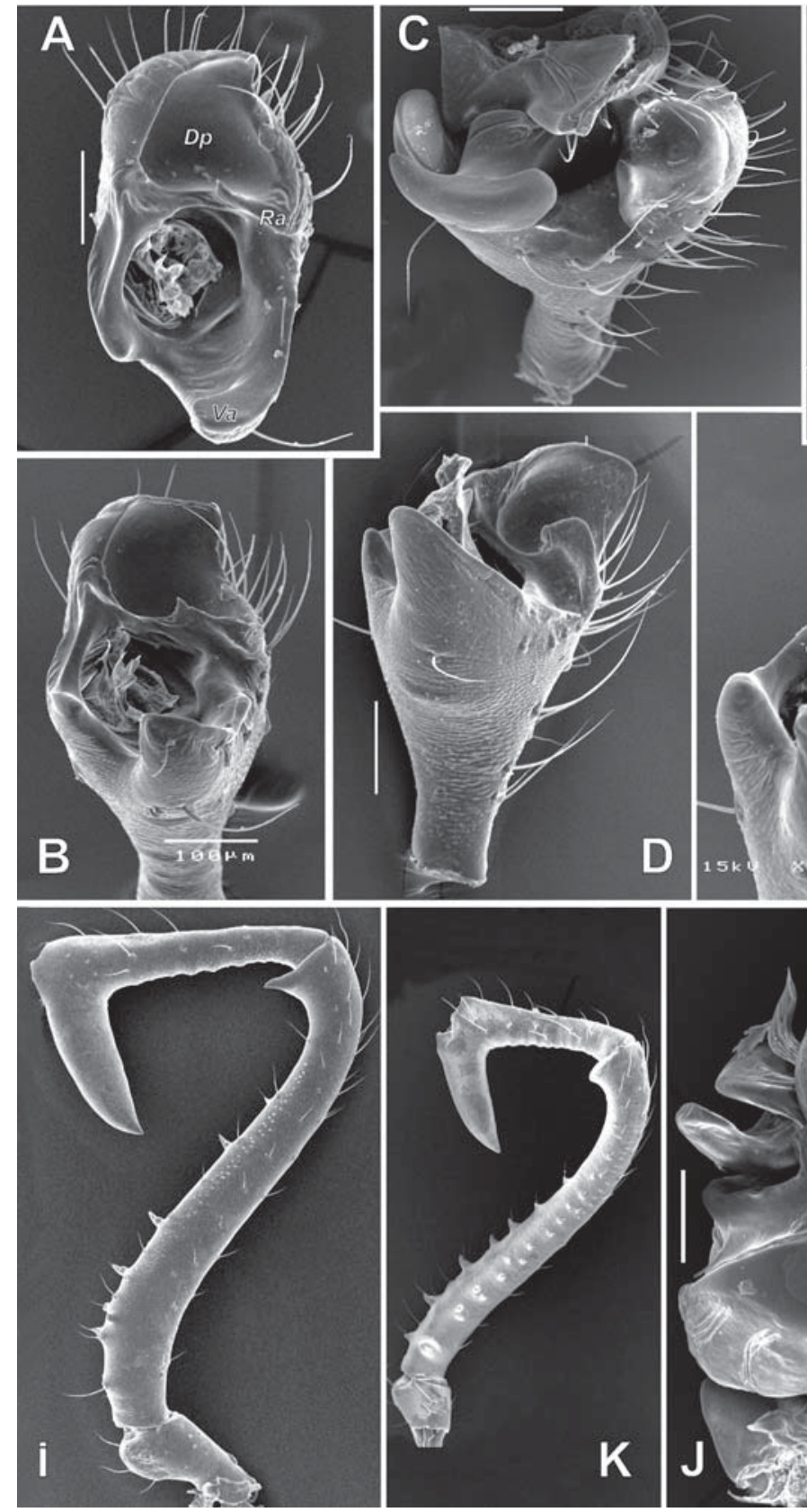

D
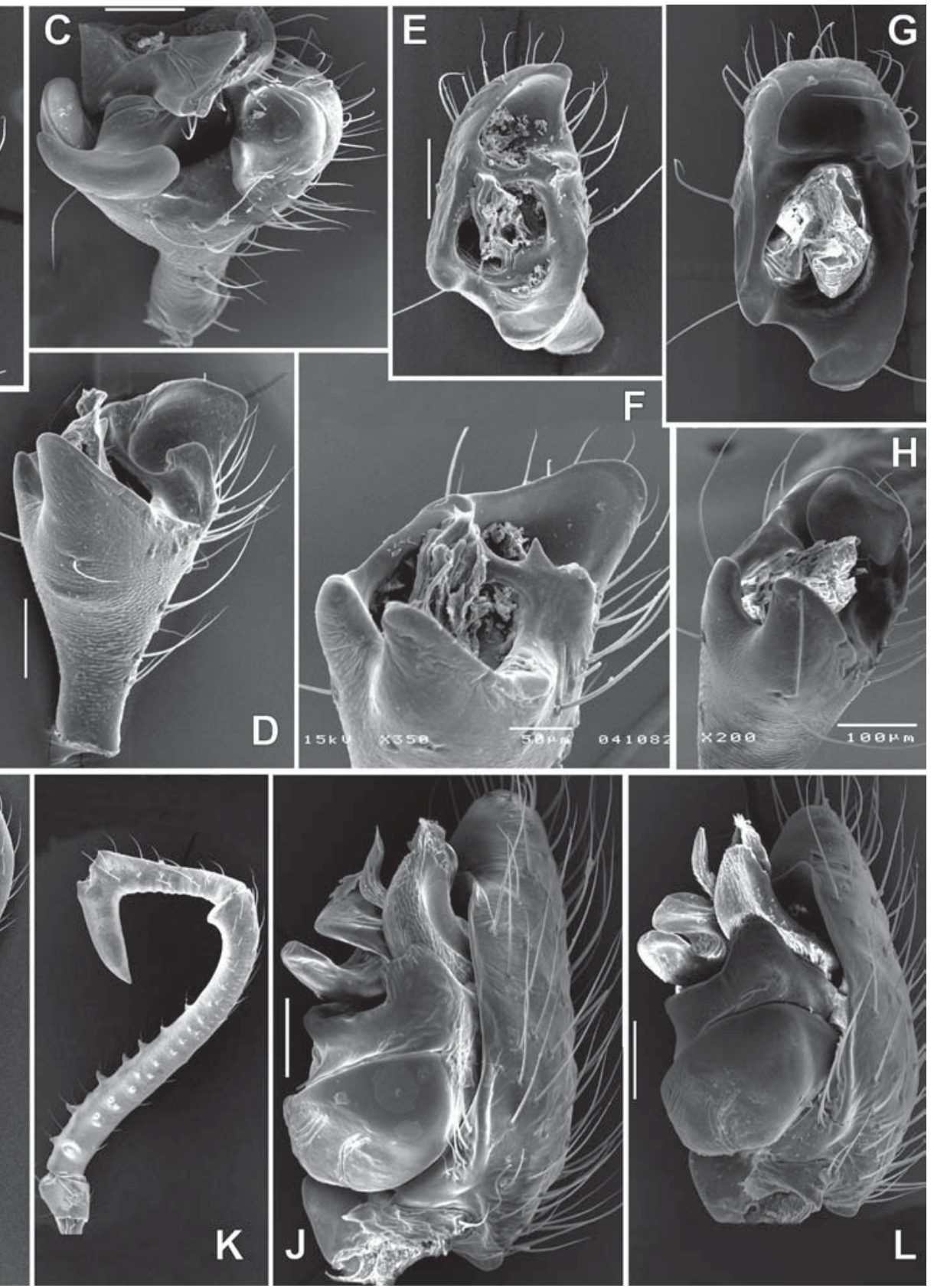

Fig. 6. Male palp of Erigone arcticola (A, B), E. hypoarctica (C, D), E. longipalpis (E, F) and E. remota (G-L). A, E, G - tibia without paracymbium, anterior; $\mathrm{C}$ - tibia with paracymbium, anterior; B - tibia anterio-ventral; D, F, H - tibia, ventro-anterior; I, K coxa-tibia, retrolateral; J, L - bulb and cymbium, retrolateral. G-J - from Pevek; K, L - from Tauysk. Scale $=0.1 \mathrm{~mm}$.

Рис. 6. Пальпа самца Erigone arcticola (A, B), E. hypoarctica (C, D), E. longipalpis (E, F) и E. remota (G-L). А, E, G - голень без парацимбиума, спереди; C - голень с парацимбиумом, спереди; В голень, спереди-снизу; D, F, H - голень, снизу-спереди; I, K тазик-голень, ретролатерально; J, L — бульбус и цимбиум, ретролатерально. G-J — экземпляры из Певека; K, L — из Тауйска. Масштаб = 0,1 мм.

range; it occurs from Western Europe to Yenisei River [Holm, 1973; Mikhailov, pers. comm.], and is also known from Central and Eastern China [Li, Lin, 2016] and Japan [Ono et al., 2009] (Fig. 10). In Japan, E. longipalpis is known from the highlands of Hokkaido (Tanikawa, pers. comm.). There are no properly documented records of this species in China although it was reported from Hebei, Jilin and Gansu. Erigone longipalpis is not known in Siberia east of the Yenisei
River and in the Russian Far East. According to Matsuda (pers. comm.) specimens from Hokkaido are almost the same as figured in our paper but have some slight differences. Given the disjunction of the range between Yenisei and Hokkaido, and the isolation of the Japanese population, it is possible to suppose that the population from Hokkaido might belong to a separate species. It is worth noting that there is also a kind of disjunction of this species in Finland. Erigone 



Fig. 7. Epigyne of Erigone remota (A, B), E. arcticola (C-G), E. longipalpis (H-L) and E. hypoarctica (M-P). A, C, H, J, M ventral; B, D, F, I, K, N, O - dorsal; E, L, P - dorso-posterior; G - posterior. Scale $=0.2 \mathrm{~mm}$.

Рис. 7. Эпигина Erigone remota (A, B), E. arcticola (C-G), E. longipalpis $(\mathrm{H}-\mathrm{L})$ и E. hypoarctica (M-P). А, C, H, J, M вентрально; В, D, F, I, K, N, О — сверху; Е, L, Р — сверху-сзади; G - сзади. Масштаб = 0,2 мм.

longipalpis is known from SW of the country and in the Arctic (Fig.10).

Erigone remota L. Koch, 1869

Figs 1E, 2C, 3A, 4A, B, F, 5J-L, 6G-L, 7A, B, 8F-J, 9,10 .

Erigone remota: Kulczyński, 1902: 552, pl. 35, f. 6, 21, 43,

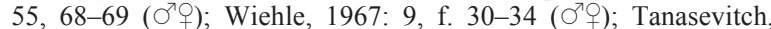
2013: 282, f. 60-62, 69, 71-72 (O'P).

MATERIAL EXAMINED: RUSSIA: $900^{7} 0^{7}$ 51 9 (ZMMU), Arkhangelsk Area, Barents Sea, Dolgiy Isl., $69^{\circ} 12^{\prime} \mathrm{N} 59^{\circ} 13^{\prime} \mathrm{E}$, Nenets Reserve, 6-28.07.2004 (O. Makarova); $30^{7} \sigma^{7}$ (ZMMU), Krasnoyarsk Prov., down flow of Kotui River, $71^{\circ} 24^{\prime} \mathrm{N} 103^{\circ} \mathrm{E}$, 06-07.2010 (O. Khrulyova); 25 O $^{7}$ T $^{7} 21$ 우, (ZMMU), Northern Yakutia, Yana River down flow, Kular Vill. env., $70.35^{\circ} \mathrm{N} 134.34^{\circ} \mathrm{E}$, July 1996 (N.N. Vinokurov); ca. $1500^{70}$ (ZMMU), NE Siberia, Magadan Area, env. of Tauysk, 59 $43^{\prime} 51^{\prime \prime} \mathrm{N} 149^{\circ} 22^{\prime} 47^{\prime \prime} \mathrm{E}$, pitfall traps, 15-26.07.2017 (M. Bizin, B. Efeikin); $180^{7} 0^{7} 5$ ㅇ (ZMMU), NE Siberia, env. of Magadan, Ola R. mouth, ca $59.567^{\circ} \mathrm{N}, 151$. $284^{\circ} \mathrm{E}$, seashore marshes, $7-14.07 .2017$ (N.E. Dokuchaev); $90^{7} \mathrm{O}^{7}$ 31 +P (ZMMU), NE Siberia, Chukotka, Chaun Bay, env. of Pevek Town, $2.2 \mathrm{~km}$ SSW Apapelgino, 69 48 $48^{\prime \prime} \mathrm{N} 170^{\circ} 36^{\prime} 23^{\prime \prime} \mathrm{E}$, seashore marshes, 13-24.07.2018 (K. Makarov, O. Makarova).
DIAGNOSIS. The male of this species is most similar to that of E. arcticola in having a rounded anterior tooth of the radix $(A t)$. It can be distinguished from similar species by the relatively smaller dorsal pocket $(D p)$ of its tibia, shorter than the retrolateral tibial apophysis (vs. pocket longer than apophysis in E. arcticola) and smaller anterior teeth of the radix (cf. Fig. 1D and E, 5A and J). Both males and females of this species in general are smaller in carapace length, and carapace femur I ratio (Fig. 9).

NOTE. The population of this species from Tauysk demonstrates the highest variability of carapace and femur I length among all species/populations compared.

COMMENTS. Here we provide comparative figures of specimens from the tundra zone (Chukotka) and coastal part of the Sea of Okhotsk (taiga zone). Almost all populations of Erigone from the Arctic zone are characterized by size polymorphism (personal observation). Here we have calculated no statistics on this subject but wish to point out certain differences and not only those in size. Although specimens from Tauysk are smaller that these from Apapelgino, males have 2 rows of spines on palpal femur, while larger specimens have only one (cf. Fig. 6K and I). 

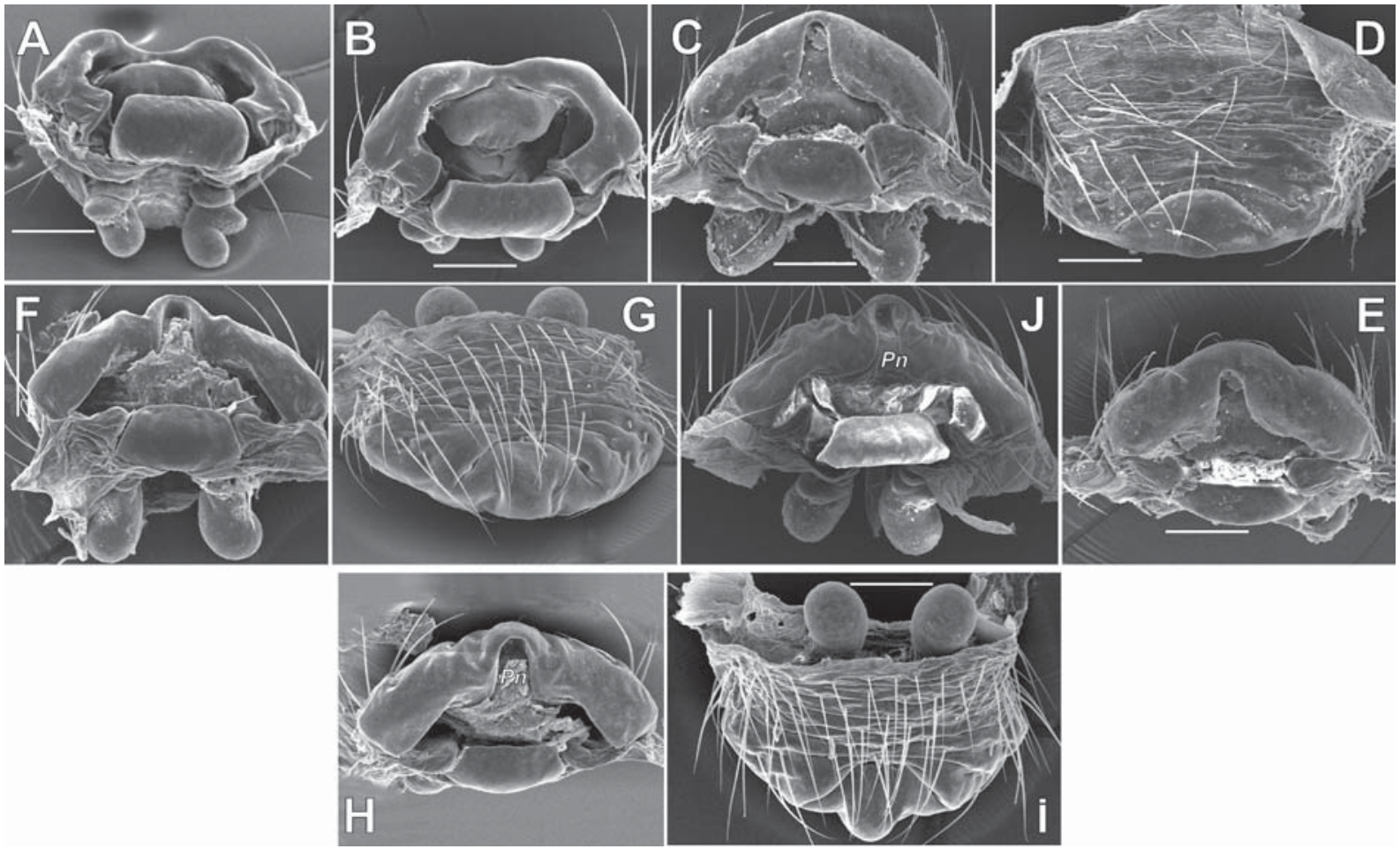

Fig. 8. Epigyne of Erigone hypoarctica (A, B), E. longipalpis (C-E) and E. remota (F-J). A - dorso-posterior; B, C, F, J - dorsal; D, $\mathrm{I}$ - ventral; G - posterior-ventral; E, H - posterio-dorsal. F-I - from Tausik; J - from Pevek.

Рис. 8. Эпигина Erigone hypoarctica (A, B), E. longipalpis (C-E) и E. remota (F-J). А — сверху-сзади; B, С, F, J — сверху; D, I снизу; G - сзади-снизу; E, Н - сзади-сверху. F-I - экземпляры из Тауйска; J - из Певека.

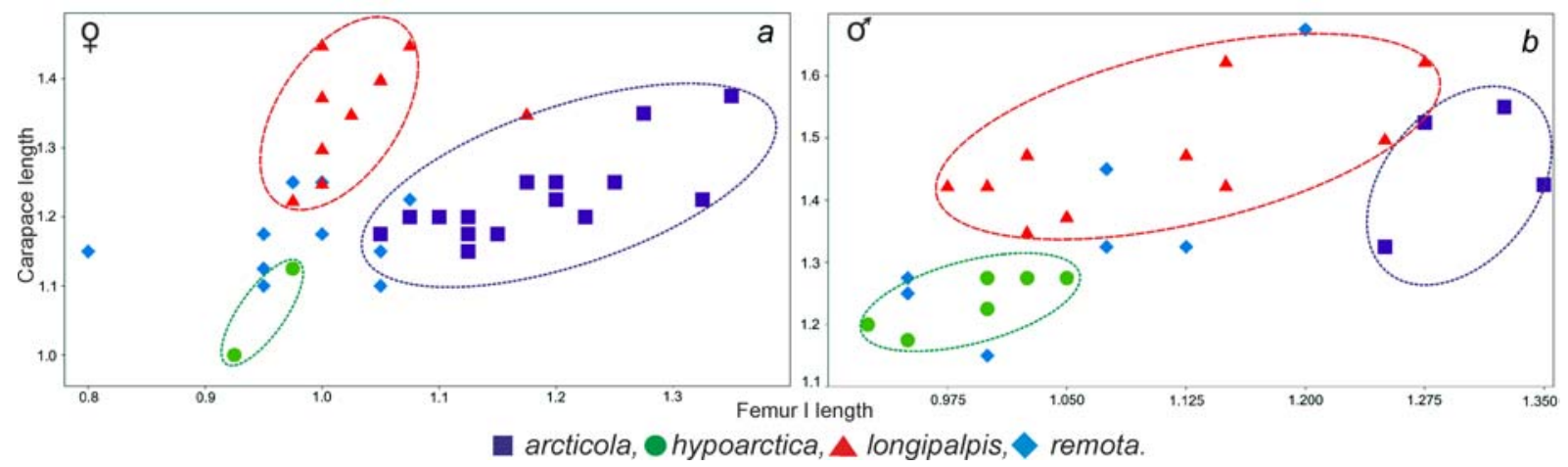

Fig. 9. Carapace length / femur I length ratio in females (a) and males (b) in four Erigone species: E. arcticola (square, Wrangel Isl.), E. hypoarctica (dot, Tauysk), E. longipalpis (triangle, SW Finland) and E. remota (diamond, Tauysk).

Рис. 9. Отношение длины головогруди к длине бедра I у самок (а) и самцов (b) четырёх видов Erigone: E. arcticola (квадрат, о. Врангеля), E. hypoarctica (кружок, Тауйск), E. longipalpis (треугольник, Ю3 Финляндия) и E. remota (ромб, Тауйск).

HABITATS. In Austria E. remota is known from 1700 to $3280 \mathrm{~m}$ [Thaler, 1999]. In Chukotka and Magadan area this species was found in seashore marshes. In the Altai this species was found in mountain tundra on elevations over $2100 \mathrm{~m}$ [Tanasevitch, 2013]. In Dolgiy Island, in Chukotka and in northern Cisokhotia E. remota was collected in large numbers on sea marshes [Marusik et al., 2016 and present data].

DISTRIBUTION. This species has a Palaearctic disjunctive range and is known (Fig. 10) from the Alps, coastal parts of the Pechora Sea [Tanasevitch, Koponen, 2007;
Marusik et al., 2016; Tanasevitch, 2017a, b], and across Siberia to Chukotka (present record). In Siberia it is known from the tundra zone and highlands of the Kazakhstan and Russian Altai [Tanasevitch, 2013] and also from Tuva [Eskov, 1994; Marusik et al., 2000]. Besides the highlands of South Siberia, it was found in seashore marshes by the Sea of Okhotsk at $59^{\circ} 30^{\prime} \mathrm{N}$ (present record). The southernmost record of this species is Central Tien Shang, Issyk-Kul' Lake in Kyrgyzstan [Tanasevitch, 1989]. This record is far from the others and might be based on misidentification. 


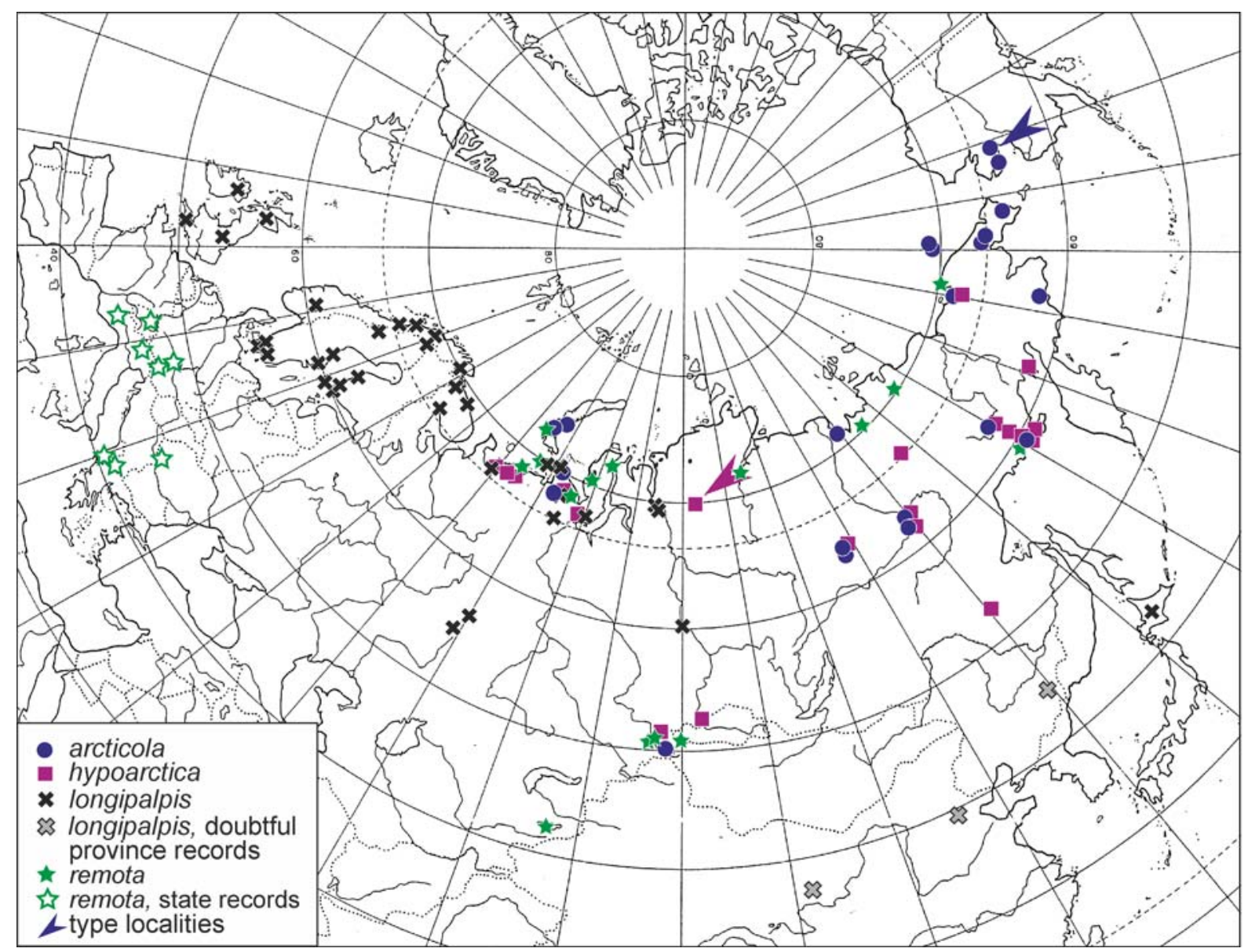

Fig. 10. Distribution of four Erigone species: E. arcticola (circle), E. hypoarctica (square), E. longipalpis (cross, in Europe only northernmost localities are shown), and E. remota (star). Arrow indicates type localities of two species.

Рис. 10. Распространение четырёх видов Erigone: E. arcticola (круг), E. hypoarctica (квадрат), E. longipalpis (крест, для Европы показаны только самые северные находки), and E. remota (звезда). Стрелки указывают типовые местообитания двух видов.

\section{Discussion about size}

Measurements of specimens of the four species taken from different populations reveals the possibility of being able to recognize three of them according to carapace/femur I length ratio: E. arcticola, E. hypoarctica and E. longipalpis (Fig. 9). Only one species, E. remota displays a high level of size variability in males and females and overlaps all the other sibling species. Because we analyzed each species from only one locality it is not evident if other populations of all four species would demonstrate the same pattern of variability. We are going to conduct further studies in this direction and analyze size variation of the same species taken from distant populations.

Acknowledgements. We thank Olga L. Makarova and Olga A. Khrulyova (Moscow, Russia) for specimens; Robert Bennett (Victoria, British Columbia, Canada), Gergin Blagoev (Guelph, Canada), Joe Bowden (Corner Brook, Newfoundland, Canada), Rod Crawford (Seattle, USA), Sarah Loboda (Ste-Anne-de-Bellevue, Québec, Canada), Mayumi
Matsuda (Kato-gun, Hokkaido, Japan) helpful information; Don Buckle (Saskatoon, Canada) for reviewing manuscript and editing English and anonymous reviewer. The study was supported in part by the Russian Foundation for Basic Research, Project \# 17-04-01603.

\section{References}

Bennett R.G., Blades D., Blagoev G., Buckle D., Copley C., Copley D., Dondale C.D., West R.C. 2017. Checklist of the spiders (Araneae) of British Columbia // Klinkenberg B. (ed.). 2018. E-Fauna BC: Electronic Atlas of the Fauna of British Columbia [www.efauna.bc.ca]. Lab for Advanced Spatial Analysis, Department of Geography, University of British Columbia, Vancouver. [accessed 12 January 2018]

Chamberlin R.V., Ivie W. 1947. The spiders of Alaska // Bulletin of the University of Utah. Vol.37. No.10. P.1-103.

Crosby C.R., Bishop S.C. 1928. Revision of the spider genera Erigone, Eperigone and Catabrithorax (Erigoneae) // New York State Museum Bulletin. Vol.278. P.1-73.

Eskov K.Y. 1989. New Siberian species of erigonine spiders (Arachnida, Aranei, Linyphiidae) // Spixiana. Vol.11. No.2. P.97-109.

Eskov K.Y. 1994. Catalogue of the linyphiid spiders of northern Asia (Arachnida, Araneae, Linyphiidae). Sofia: Pensoft Publishers. $144 \mathrm{p}$. 
Harvey P.R., Nellist D.R., Telfer M.G. (eds.). 2002. Provisional atlas of British spiders (Arachnida, Araneae). Vol.1. P.1-214.

Holm Å. 1960. On a collection of spiders from Alaska // Zoologiska Bidrag från Uppsala. Vol.33. P.109-134.

Holm Å. 1973. On the spiders collected during the Swedish expeditions to Novaya Zemlya and Yenisey in 1875 and $1876 / /$ Zoologica Scripta. Vol.2. No.2-3. P.71-110.

ICZN 1987. Opinion 1421. Erigone Audouin, [1826] (Arachnidae, Araneae): Erigone longipalpis Sundevall, 1830, designated as type species // Bulletin of Zoological Nomenclature. Vol.44. No.1. P.50-51.

Koponen S. 2000. Spiders (Araneae) on sandy islands in the southwestern archipelago of Finland // Ekologia (Bratislava). Vol.19. Suppl.4. P.79-85.

Kulczyński W. 1902. Erigonae Europaeae. Addenda ad descriptions // Bulletin international de l'Académie des sciences de Cracovie. Vol.8. P. 539-560.

Lehtinen P.T., Kleemola A. 1962. Studies on the spider fauna of the southwestern archipelago of Finland. I // Archivum Societatis Zoologicae Botanicae Fennicae 'Vanamo'. Vol.16. No.1. P.97-114.

Li S.Q., Lin Y.C. 2016. [Species Catalogue of China. Vol.3 Animalia. Invertebrata (I) Arachnida: Araneae]. Beijing: Science Press. 578 pp. [In Chinese]

Marusik Y.M., Koponen S., Makarova O.L. 2016. A survey of spiders (Araneae) collected on the arctic island of Dolgiy $\left(69^{\circ} 12^{\prime} \mathrm{N}\right)$, Barents Sea // Arachnology. Vol.17. No.1. P.1024.

Marusik Yu.M., Koponen S., Vinokurov N.N., Nogovitsyna S.N 2002. Spiders (Aranei) from northernmost forest-tundra of northeastern Yakutia $\left(70^{\circ} 35^{\prime \prime} \mathrm{N}, 134^{\circ} 34^{\prime \prime} \mathrm{E}\right)$ with description of three new species // Arthropoda Selecta. Vol.10 (for 2001). No.4. P.351-370.

Marusik Yu.M., Logunov D.V., Koponen S. 2000. Spiders of Tuva, south Siberia. Magadan: Institute for Biological Problems of the North. 253 p.

Millidge A.F. 1984. The taxonomy of the Linyphiidae, based chiefly on the epigynal and tracheal characters (Araneae: Linyphiidae) // Bulletin of the British Arachnological Society. Vol.6. Pt.6. P.229-267.

Muster C., Hänggi A. 2009. The Erigone psychrophila group in the Alps (Araneae: Linyphiidae) // Contributions to Natural History. Vol.12. P.987-1005.
Nekhaeva A.A. 2015. Spider (Arachnida, Aranei) assemblages of some habitats from the Kola Gulf Coast: phenological aspect // Entomological Review. Vol.95. No.4. P.544-556.

Ono H., Matsuda M., Saito H. 2009. Linyphiidae, Pimoidae // Ono H. (ed.). The spiders of Japan with keys to the families and genera and illustrations of the species. Kanagawa: Tokai University Press. P.253-344.

Palmgren P. 1976. Die Spinnenfauna Finnlands und Ostfennoskandiens. VII. Linyphiidae 2 // Fauna Fennica. Vol.29. P.1-126.

Platnick N.I. 2014. The world spider catalog, version 15. American Museum of Natural History, online at http://research.amnh.org/ entomology/spiders/catalog/index.html Accessed on 18.12.2018.

Roberts M.J. 1987. The spiders of Great Britain and Ireland. Vol. 2: Linyphiidae and check list. Harley Books, Colchester, England. $204 \mathrm{p}$

Tanasevitch A.V. 1989. The linyphiid spiders of Middle Asia (Arachnida: Araneae: Linyphiidae) // Senckenbergiana biologica. Vol.69. No.1-3. P.83-176.

Tanasevitch A.V. 2013. The linyphiid spiders of the Altais, southern Siberia (Aranei: Linyphiidae) // Arthropoda Selecta. Vol.22. No.3. P.267-306

Tanasevitch A.V. 2017a. New records of spiders (Aranei) from the Russian Arctic // Arthropoda Selecta. Vol.26. No.1. P.77-82.

Tanasevitch A.V. 2017b. Spiders (Aranei) of the Novaya Zemlya Archipelago and the Vaygach Island, Russia // Arthropoda Selecta. Vol.26. No.2. P.145-153.

Tanasevitch A.V., Koponen S. 2007. Spiders (Aranei) of the southern tundra in the Russian Plain // Arthropoda Selecta. Vol.15 (for 2006). No.4. P.295-345.

Thaler K. 1999. Beiträge zur Spinnenfauna von Nordtirol - 6 . Linyphiidae 2: Erigoninae (sensu Wiehle) (Arachnida: Araneae) // Veröffentlichungen des Museum Ferdinandeum (Innsbruck). Bd.79. S.215-264.

Wiehle H. 1960. Spinnentiere oder Arachnoidea (Araneae). XI. Micryphantidae-Zwergspinnen // Die Tierwelt Deutschlands. Lfg.47. S.1-620.

Wiehle H. 1967. Beiträge zur Kenntnis der deutschen Spinnenfauna, V. (Arachnida, Araneae) // Senckenbergiana Biologica. Bd.48. S.1-36.

WSC. 2019. World Spider Catalog. Version 19.5. Natural History Museum Bern, online at http://wsc.nmbe.ch, accessed on 12.01.2019.

Responsible editor Kirill G. Mikhailov 